\title{
SOME POSSIBILITIES OF PROSTANOID SYNTHESIS FROM BICYCLIC EPOXIDE SYNTHONS USING CUPRATE AND LITHIUM ALKYNIDE $\cdot \mathrm{BF}_{3}$ REAGENTS *
}

(Presented by 0 . Lille)

Bicyclic systems are highly attractive prostaglandin synthons because their inherent locked stereochemistry may be used to define the stereochemistry of prostanoids. To these bicyclic electrophiles belong also bicyclic epoxides. The main idea of this approach is as follows

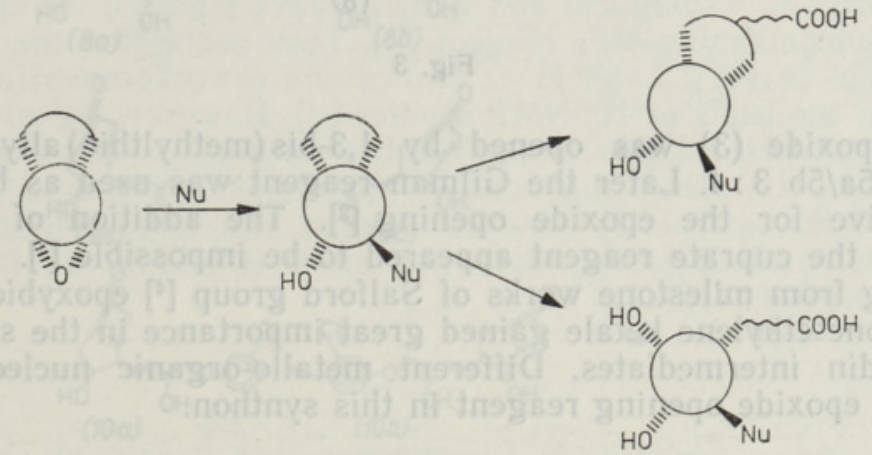

Fig. 1

The stereochemistry of hydroxy functions as well as the side chains are defined by the initial stereochemistry of bicyclic epoxide.

In this report I deal with some aspects and results obtained in the laboratory of prostanoid chemistry using cuprate and lithium alkynide $\cdot \mathrm{BF}_{3}$ reagents in the synthesis of prostanoid intermediates from the following bicyclic epoxides

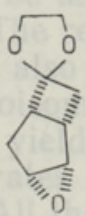

(1)

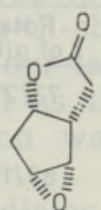

(2)

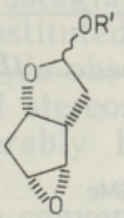

(3)

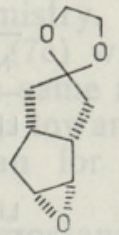

(4)

Fig. 2

Bicyclic epoxide was first used in prostaglandin synthesis by E. J. Corey and R. Noyori [ $\left.{ }^{1}\right]$. They have shown that bicyclic epoxide (3) is a useful prostaglandin synthon (Fig. 3).

* Lecture held at the symposium "Synthesis and Research of Prostaglandins". Tallinn, October, 1986. 


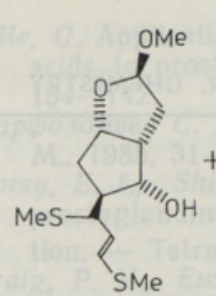

(5b)

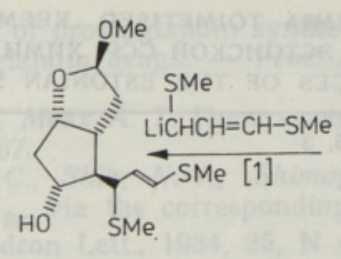

(5a)

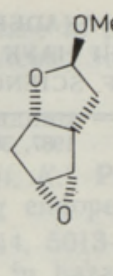

(3)

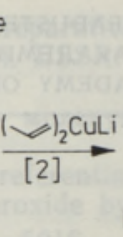

Ho

(4a)

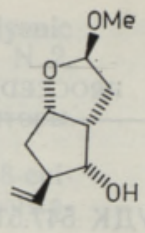

(4b)
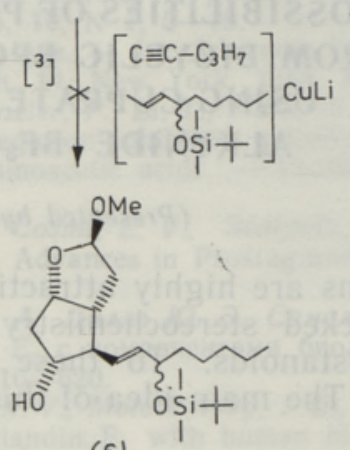

(6)

Fig. 3

Thus epoxide (3) was opened by 1,3-bis (methylthio) allyllithium at a ratio of $5 \mathrm{a} / 5 \mathrm{~b} 3: 4$. Later the Gilman reagent was used as being more regioselective for the epoxide opening $\left[{ }^{2}\right]$. The addition of the whole $\omega$-chain by the cuprate reagent appeared to be impossible $\left[{ }^{3}\right]$.

Starting from milestone works of Salford group [ $\left.{ }^{4}\right]$ epoxybicyclo[3.2.0]heptane-6-one ethylene ketale gained great importance in the synthesis of prostaglandin intermediates. Different metallo-organic nucleophiles are used as an epoxide opening reagent in this synthon.

Table 1

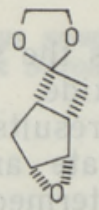

(1)

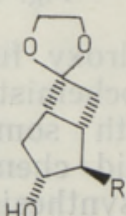

(a)

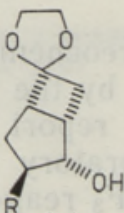

(b)

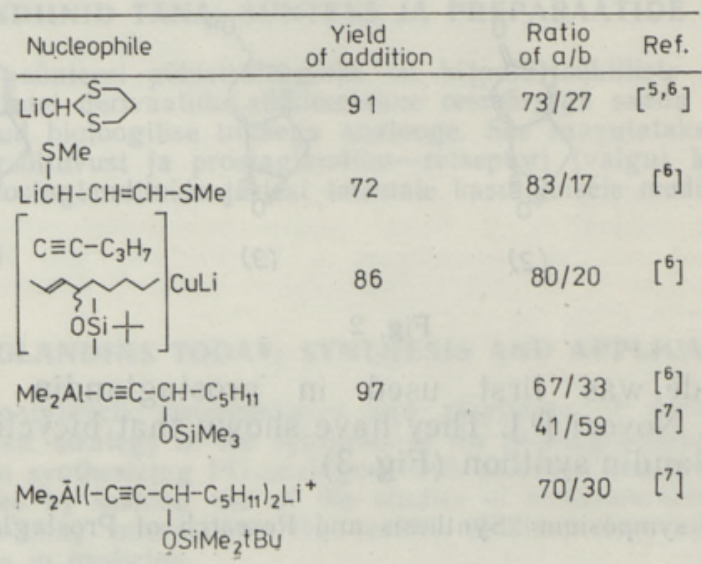


As can be seen from Table 1, the Corey reagent opens the epoxide function in synthon (1) more regioselectively than in lactolepoxide synthon (3) demonstrated above. From the point of view of the prostanoid synthesis, cuprate and alanate reagents are more perspective. The contradiction of the results in $\left[^{6}\right]$ and $\left[{ }^{7}\right]$ is probably due to the complicity of alane/alanate reagents.

As a compliment to these well-known facts, some results of oxirane opening in epoxide (1) by cuprate reagents obtained in our laboratory are given in Table 2 .

Table 2

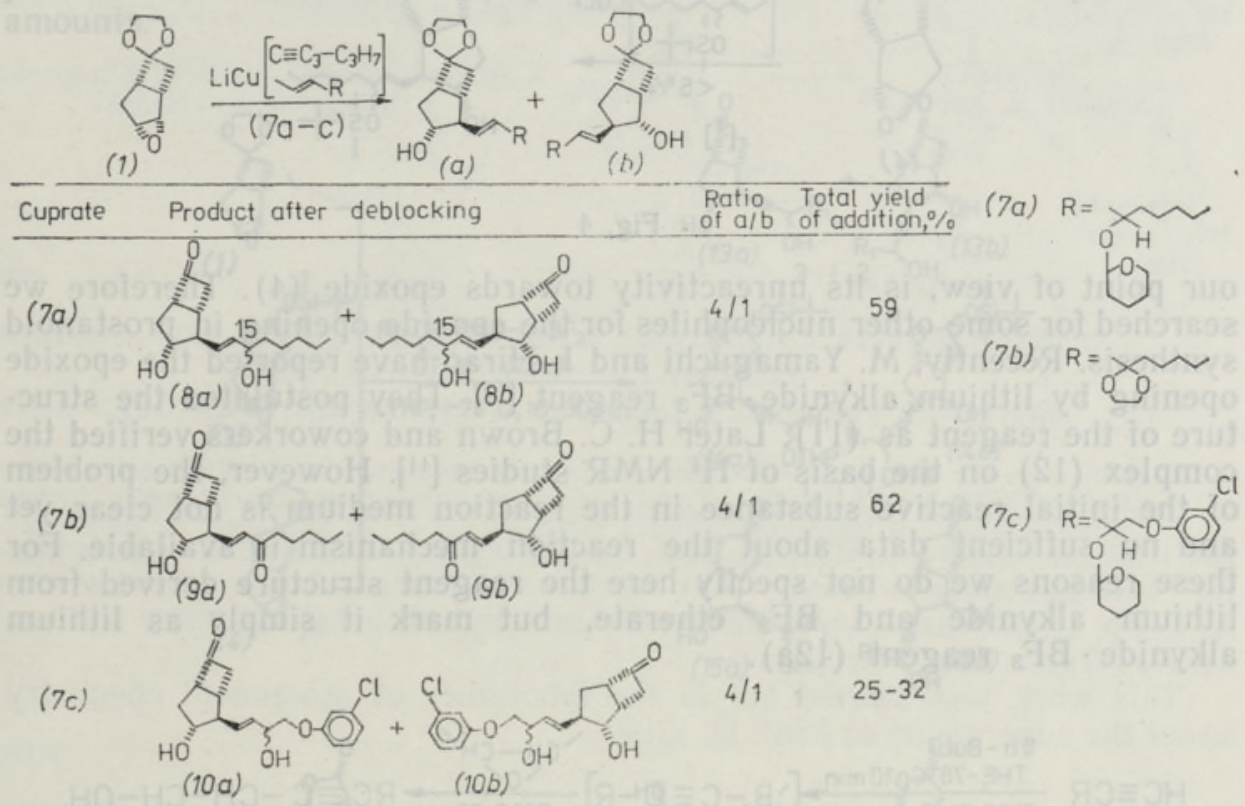

As is known, the epoxide opening with cuprate (7a) has a serious disadvantage: it completely lacks stereoselectivity towards the C15 hydroxyl function. This disadvantage can be overcome by using ketale cuprate (7b) which leads to ketoenones (9a) and (9b) at a $4 / 1$ ratio. The ketoenone (9a) is easily oxidized into the corresponding lactone which can be reduced in a stereoselective manner into lactonediol by known methods. It should also be mentioned that (9a) and (9b) are easily separable by simple crystallization. For these reasons ketale cuprate $(7 \mathrm{~b})$ can be used as a valuable tool in prostaglandin chemistry.

The reaction of $\mathrm{m}-\mathrm{Cl}$-phenoxy-substituted cuprate (7c) with epoxide(1) was also studied in our laboratory. We observed the same ratio, $4: 1$, for regioisomers as well as the lack of stereoselectivity towards C15. Only the yield of addition was considerably lower than for two previous cuprates $\left[{ }^{8}\right]$.

All these intermediates have been converted into prostanoids by known methods.

As to lactone epoxide (2), its unreactivity towards cuprates was demonstrated by E. J. Corey. Surprisingly enough, the epoxide (4) was also unreactive towards cuprates under usual conditions [ $\left.{ }^{9}\right]$. Though being short and flexible, the cuprate synthesis suffers from several disadvantages. First, a large amount of $\omega$-chain is required, the $\omega$-chain precursor cannot be recovered from the unreacted cuprate. The second disadvantage is the long reaction time (usually $10-24 \mathrm{~h}$ ) at uncomfortable temperature $\left(-20--30^{\circ} \mathrm{C}\right)$. The most unfavourable disadvantage, from 


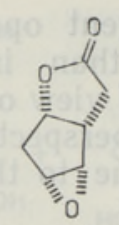

(2)

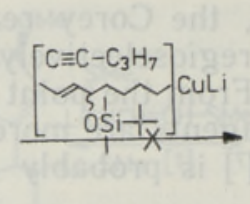

HO
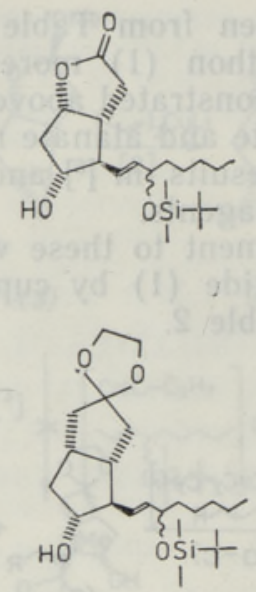

(4)

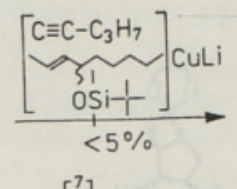

$\left[{ }^{7}\right]$

Fig. 4

our point of view, is its unreactivity towards epoxide (4). Therefore we searched for some other nucleophiles for the epoxide opening in prostanoid synthesis. Recently, M. Yamaguchi and I. Hirao have reported the epoxide opening by lithium alkynide $\cdot \mathrm{BF}_{3}$ reagent $\left[{ }^{10}\right]$. They postulated the structure of the reagent as (11). Later $\mathrm{H}$. C. Brown and coworkers verified the complex (12) on the basis of $\mathrm{H}^{1}$ NMR studies [11]. However, the problem of the initial reactive substance in the reaction medium is not clear yet and no suffcient data about the reaction mechanism is available. For these reasons we do not specify here the reagent structure derived from lithium alkynide and $\mathrm{BF}_{3}$ etherate, but mark it simply as lithium alkynide $\cdot \mathrm{BF}_{3}$ reagent $(12 \mathrm{a})$.

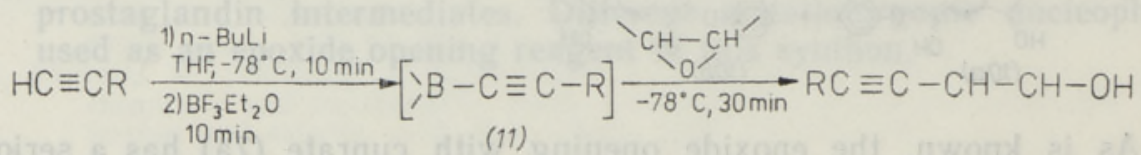

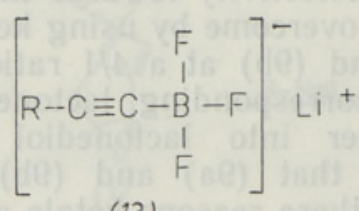

(12)

$$
\mathrm{RC} \equiv \mathrm{C}-\mathrm{Li} \cdot \mathrm{BF}_{3}
$$

Fig. 5

In Fig. 6 there are presented some results of using lithium alkynide $\cdot \mathrm{BF}_{3}$ reagent in the oxirane opening reaction with epoxides (1) (4) in prostanoid synthesis [9, 12, 13].

Epoxide (1) reacts readily with lithium alkynide $\cdot \mathrm{BF}_{3}$ reagent affording after deblocking ketone diols (13a) and (13b) in the ratio of $56: 44$. The reaction proceeds at $-78^{\circ} \mathrm{C}$ in $10-30$ minutes. This reaction shows a complete lack of stereoselectivity towards C15 hydroxyl function. These regioisomers are easily separable on silica gel but $15 \alpha / 15 \beta$-isomers for compound (13a) are inseparable [ $\left.{ }^{14}\right]$. For regioisomers (13b), $\alpha / \beta$-isomers are separable. The ratio of $15 \alpha / 15 \beta$-isomers was separately determined by HPLC after the reduction of $13-14$ triple bond yielding easily separable allylic alcohols $\left[{ }^{14}\right]$. Epoxide (3) reacts also with lithium alkynide $\cdot \mathrm{BF}_{3}$ reagent, but in this case there is no regioselectivity as well as no stereoselectivity towards C15 hydroxyl function. 
It can be stressed that epoxide (4) which is relatively unreactive towards cuprate reagent, readily reacts with lithium alkynide. $\mathrm{BF}_{3}$ reagent affording lactonediols (15a) and (15b) at the ratio of $1: 1$. In this way, synthon (4) can be used in carbacyclin synthesis, giving one of the simplest and shortest way to carbacyclins [ $\left.{ }^{9}\right]$.

Epoxide (2), which is unreactive towards cuprate reagents, reacts with lithium alkynide $\cdot \mathrm{BF}_{3}$ reagents yielding a complex mixture. Using the model lithium octynide $\cdot \mathrm{BF}_{3}$ reagent, we were able to establish that the addition reaction proceeds mainly in a 1,2-manner with a lactone carbonyl function. Enynol (16) was separated from the reaction mixture in $35 \%$ yield. The desired lactonol (17) was found to be present only in trace amounts.
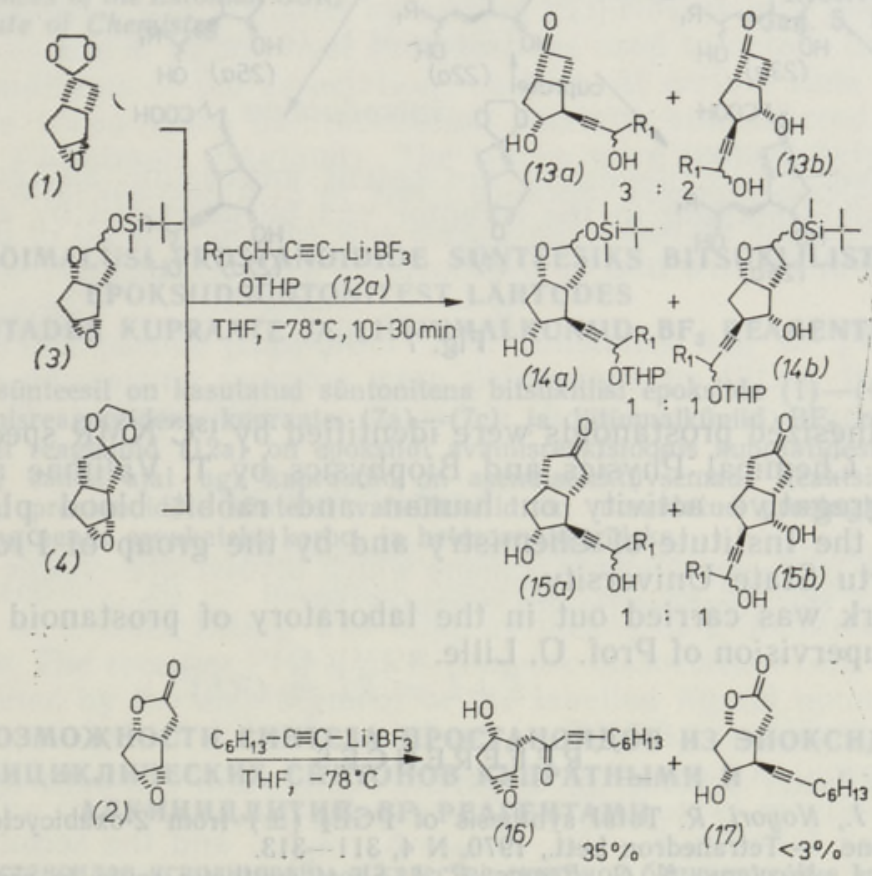

Fig. 6

Summarizing the results obtained by us using lithium alkynide $\cdot \mathrm{BF}_{3}$ reagents in the synthesis of prostanoid intermediates, it can be said that regardless of the low regioselectivity of the reagent towards epoxide (1) and of the lack of regioselectivity towards epoxides (3) and (4), the lithium alkynide $\cdot \mathrm{BF}_{3}$ reagent serves as a simple and convenient tool for the synthesis of several prostanoid intermediates. It can also be mentioned that lithium alkynide $\mathrm{BF}_{3}$ reagent is useful for the synthesis of both regioisomeric ketonediols. As is known, in some cases both isomers are valuable. Moreover, this approach enables us to recover unconsumed initial acetylene and use it repeatedly.

In Fig. 7 there are demonstrated some ways of converting the abovementioned bicyclic intermediates into prostanoids [ $\left.{ }^{12}\right]$.

As can be seen, the most universal intermediate is ketonediol (13a) from which all the other intermediates can be synthesized. In some cases, however, direct synthesis of the proper intermediate from the corresponding epoxide is more favourable, for example in the case of ketonediol (15a).

The same transformations shown in the present paper were also carried out starting from the corresponding regioisomers. 


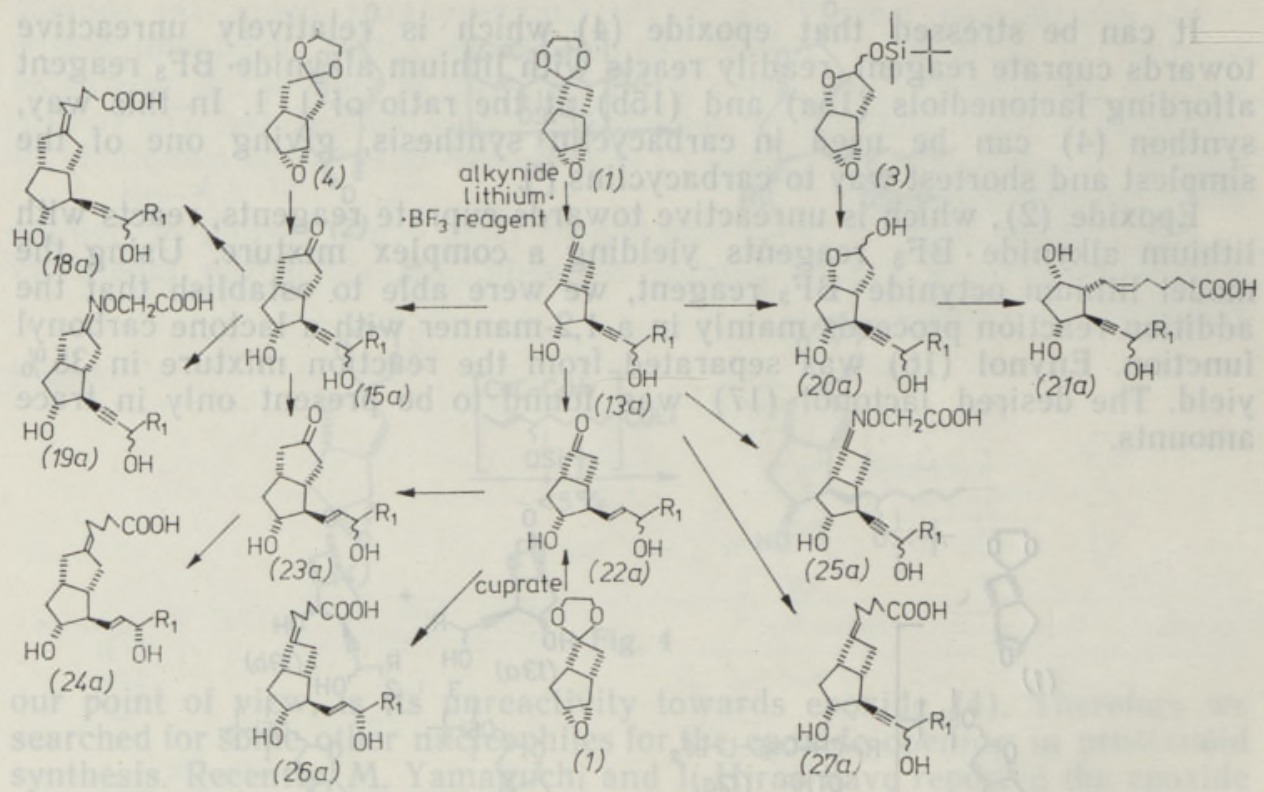

Fig. 7

The synthesized prostanoids were identified by ${ }^{13} \mathrm{C}$ NMR spectra at the Institute of Chemical Physics and Biophysics by T. Välimäe and tested for antiaggregative activity on human and rabbit blood platelets by A. Lopp at the Institute of Chemistry and by the group of Prof. R. Teesalu at Tartu State University.

This work was carried out in the laboratory of prostanoid chemistry under the supervision of Prof. U. Lille.

\section{REFERENCES}

1. Corey, E. J., Noyori, R. Total synthesis of $\mathrm{PGE}_{2}( \pm)$ from 2-oxabicyclo[3.3.0]oct-6en-3-one. - Tetrahedron Lett., 1970, N 4, 311-313.

2. Corey, E. J., Nicolaou, K. C., Beams, P. J. Short synthetic route to prostaglandins utilizing positioselective epoxide opening by the vinyl Gilman reagent. - Tetrahedron Lett., 1974, N 28, 2439-2440.

3. Newton, R. F., Roberts, S. M. Steric control in prostaglandin synthesis involving bicyclic and tricyclic intermediates. - Tetrahedron, 1980, 36, N 15, 2163-2196.

4. Newton, R. F., Howard, C. C., Reynolds, O. P., Wadsworth, A. H., Crossland, N. M., Roberts, $S$. $M$. Novel synthesis of $\mathrm{PGE}_{2}$, involving regioselective ring opening of a 2,3-endo-epoxybicyclo[3.2.0]heptane-6-one acetal with a mixed organocuprate reagent. - J. Chem. Soc. Chem. Comm., 1978, N 15, 662-663.

5. Bartmann, W., Beck, G., Knolle, J., Rupp, R. H. Synthesis of stable prostacyclin analogues. - Tetrahedron Lett., 1982, 23, N 36, 3647-3650.

6. Cave, R. J., Howard, C. C., Klinkert, G., Newton, R. Б., Reynolds, D. P., Wadsworth, A. H., Roberts, S. M. Regioselective reactions of 2,3-endo-epoxy-bicyclo[3.2.0]heptanone ethylene acetal involving organometallic reagents. - J. Chem. Soc. Perkin Trans. I, 1979, N 12, 2954-2958.

7. Matthews, R. S., Eickhoff, J. D. The regioselectivity of epoxide-opening reactions using alkynylaluminium reagents. - J. Org. Chem., 1985, 50, N 20, 3923-3925.

8. Лопп М. Н., Лилле Ю. Э., Парве О. В., Паю А. Н., Няреп М. Э., Вялимяэ Т. К. Производные эндо-3-гидрокси-анти-2 (4-фенокси-3-гидрокси-1E-бутенил) -бицикло [3.2.0]гептан-6-она. - Открытия, нзобретения, 1986, № 6, авт. свид. СССР № 1211251 .

9. Парве О., Пальс А., Лыхмус М., Вялимяэ Т., Лахе Л., Лопп М., Лилле Ю. Синтез простагландинов F и I ряда. 2. Синтез ( \pm ) 13,14 -дидегидро-6,9 $\alpha$-метанопростагландина $\mathrm{I}_{2}$ через этиленовый кеталь 2,3-эндо-эпоксибицикло[3.3.0]октан-7-она. Изв. АН ЭССР. Хим., 1985, 34, № 4, 285-291.

10. Yamaguchi, M., Hirao, I. An efficient method for the alkynylation of oxiranes using alkynyl boranes. - Tetrahedron Lett., 1983, 24, N 4, 391-394. 
11. Brown, H. C., Racherla, U. S., Singh, S. M. Improved highly efficient synthesis of $\alpha, \beta$-acetylenic ketones. Nature of the intermediate from the reaction of lithium acetylide with boron trifluoride etherate. - Tetrahedron Lett., 1984, 25, N 23, $2411-2414$

12. Lopp, M., Parve, O., Lõhmus, M., Müraus, A., Pals, A., Välimäe, T., Lille, U. Synthesis of prostanoids via alkynyl borate oxirane opening. - In: Abstr. of Papers. Fourth Europ. Symp. on Organic Chem. Aix-en-Provence (France) 1985, OC-29.

13. Lopp, M., Parve, O., Paju, A., Niidas, P., Müraus, A., Lille, O. Contribution of lithium alkynide $\mathrm{BF}_{3}$ reagents to prostanoid synthesis. - In: Programme and Abstracts of Papers IUPAC VI International Conference on Organic Synthesis. (Moscow), 1986, B-063.

14. Лыхмус М., Парве О., Мюраус А., Кангер Т., Лопп М., Лилле Ю. Определение изомерного состава продуктов реакции раскрытия бициклооксирановых синтонов простаноидов методом высокоэффективной жидкостной хроматографии. - Изв. АН ЭССР. Хим., 1986, 35, № 3, 197-204.
Academy of Sciences of the Estonian SSR, Institute of Chemistry
Received
Jan. 5, 1987

M. $L O P P$

\section{MONINGAID VÕIMALUSI PROSTANOIDIDE SUNTEESIKS BITSUKLILISTEST EPOKSIIDSUNTONITEST LÄHTUDES NING KASUTADES KUPRAATE JA LIITIUMALKUNIID $\cdot \mathrm{BF}_{3}$ REAGENTE}

Prostanoidide sünteesil on kasutatud süntonitena bitsüklilisi epoksiide (1)-(4) ning oksiraanringi avamisreagentidena kupraate $(7 \mathrm{a})-(7 \mathrm{c})$ ja liitiumalküniid $\cdot \mathrm{BF}_{3}$ reagente (12a). On leitud, et reagendid (12a) on epoksiidi avamisreaktsioonis kupraatidest reaktsioonivōimelisemad, samal ajal aga kupraadid on asendiselektiivsemad. Reaktsioonides saadud bitsüklilised prostanoidide sünteesi vaheühendid on muundatud prostaglandiinideks $\mathrm{F}_{2 \alpha}$ ja $\mathrm{I}_{2}$ ning nende arvukateks karbo- ja heteroanaloogideks.

\section{М. лопп}

\section{НЕКОТОРЫЕ ВОЗМОЖНОСТИ СИНТЕЗА ПРОСТАНОИДОВ ИЗ ЭПОКСИДНЫХ БИЦИКЛИЧЕСКИХ СИНТОНОВ КУПРАТНЫМИ И АЛКИНИДЛ ИТИИ - ВF $_{3}$-РЕАГЕНТАМИ}

В синтезе простаноидов использованы в качестве синтонов бициклические эпоксиды (1) - (4), а в качестве реагентов раскрытия оксиранового кольца - купратные (7a)(7c) и алкинидлитий $\cdot \mathrm{BF}_{3}$-реагенты (12a). Установлено, что реакционная способность реагентов (12a) по отношению к эпоксидам выше, а региоселективность их при раскрытии оксиранов ниже, чем купратов $(7 \mathrm{a})-(7 \mathrm{c})$. Полученные при раскрытии разные бициклические интермедиаты превращены в простагландины $\mathrm{F}_{2 \alpha}, \mathrm{I}_{2}$ и их многочисленные карбо- и гетероаналоги. 